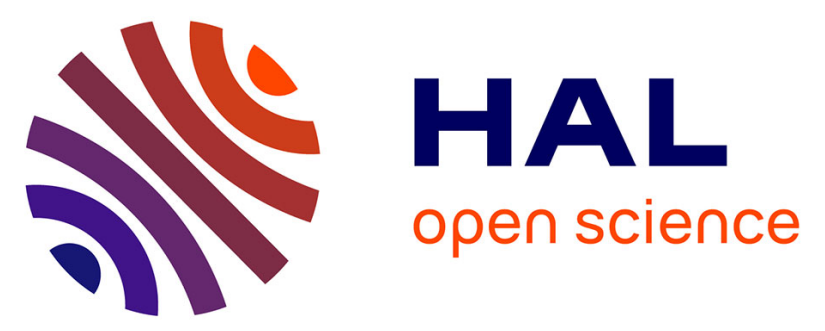

\title{
Archaeology and Archaeometry of Ceramics of the Roman City of Thaenae (Tunisia): between Inland Roman Africa and the Mediterranean Basin
}

Rémi Rêve, Jean-Paul Ambrosi, Claudio Capelli, Michel Bonifay, Abdelhamid Barkaoui

\section{To cite this version:}

Rémi Rêve, Jean-Paul Ambrosi, Claudio Capelli, Michel Bonifay, Abdelhamid Barkaoui. Archaeology and Archaeometry of Ceramics of the Roman City of Thaenae (Tunisia): between Inland Roman Africa and the Mediterranean Basin. First Conference of the Arabian Journal of Geosciences (CAJG), Nov 2018, Hammamet, Tunisia. 2018. halshs-01959193

\section{HAL Id: halshs-01959193 \\ https://shs.hal.science/halshs-01959193}

Submitted on 18 Dec 2018

HAL is a multi-disciplinary open access archive for the deposit and dissemination of scientific research documents, whether they are published or not. The documents may come from teaching and research institutions in France or abroad, or from public or private research centers.
L'archive ouverte pluridisciplinaire HAL, est destinée au dépôt et à la diffusion de documents scientifiques de niveau recherche, publiés ou non, émanant des établissements d'enseignement et de recherche français ou étrangers, des laboratoires publics ou privés. 
Archaeology and Archaeometry of Ceramics of the Roman City of Thaenae (Tunisia): between inland Roman Africa and the Mediterranean Basin

Rémi Rêve (1) (2), Jean-Paul Ambrosi (3), Claudio Capelli (4), Michel Bonifay (1),

Abdelhamid Barkaoui (2)

(1) Aix Marseille Univ, CNRS, CCJ, Aix-en-Provence, France, (2) Sfax University, LERIC, 3029 Sfax, Tunisia, (3) Aix Marseille Univ, CNRS, IRD, CDF, INRA, CEREGE BP 80, 13545 Aix-en-Provence, France, (4) Università degli Studi di Genova, DISTAV, 16126 Genoa, Italy

\section{Introduction / Research Motivation \\ This research is part of a PhD thesis, started in 2017 under the supervision of Aix Marseille University (France)} and Sfax University (Tunisia). It is focused on the archaeological and archaeometric characterization of the African ceramics of the Roman site of Thaenae/Thyna (Tunisia) and namely of the local production.

- Located $12 \mathrm{~km}$ south of Sfax (Fig. 1), Thaenae was an important coastal city in the south of the Roman Province of Byzacena. At the end of the $3^{\text {rd }}$ century AD, a monumental rampart was built, which included the perimeter of the city of the Early Roman Empire and $2^{\text {nd }}-3^{\text {rd }} c$. AD craft installations, in particular workshops of amphorae, the main ceramic production in Thaenae. This wall disrupted the organization of the earlier workshops, that moved outside the city and had been in function until the $5^{\text {th }}$ century AD. This configuration and the remains of numerous workshops discovered on the ground indicate a strong economic activity with maritime contacts.

- Because of its strategic position, Thaenae was at the crossroads of trade routes between inland Africa and the Mediterranean. The characterization of the local pottery production (amphorae and common wares) and the identification of the imported wares (African Red Slip Wares not locally produced) is aimed at contributing to reconstruct the exchange networks of the city. As a matter of fact, preliminary archaeological expertise shows that African Red Slip Ware was imported from inland regions together with agricultural goods (olive oil and wine), involving strong trade contacts.

- Since the beginning of the 2000s, the combined typological, petrographical (by optical microscopy) and geochemical (by classical X-ray Fluorescence methods) characterization of African pottery from several important Roman workshops found in Tunisia has provided significant data for provenance studies in the Mediterranean consumption sites and new integrated typological-archaeometric classifications $[1,2]$. In the continuity of these researches, a new method is presented here, based on a combined approach between archaeological, petrographical and geochemical data by non-destructive X-ray Fluorescence (XRF).

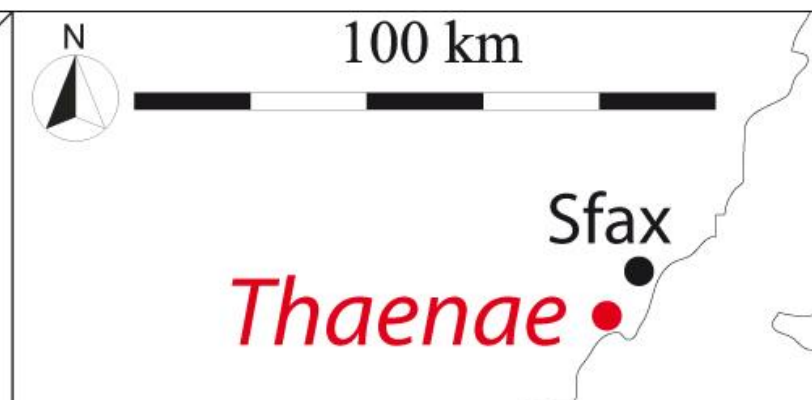

Gabès

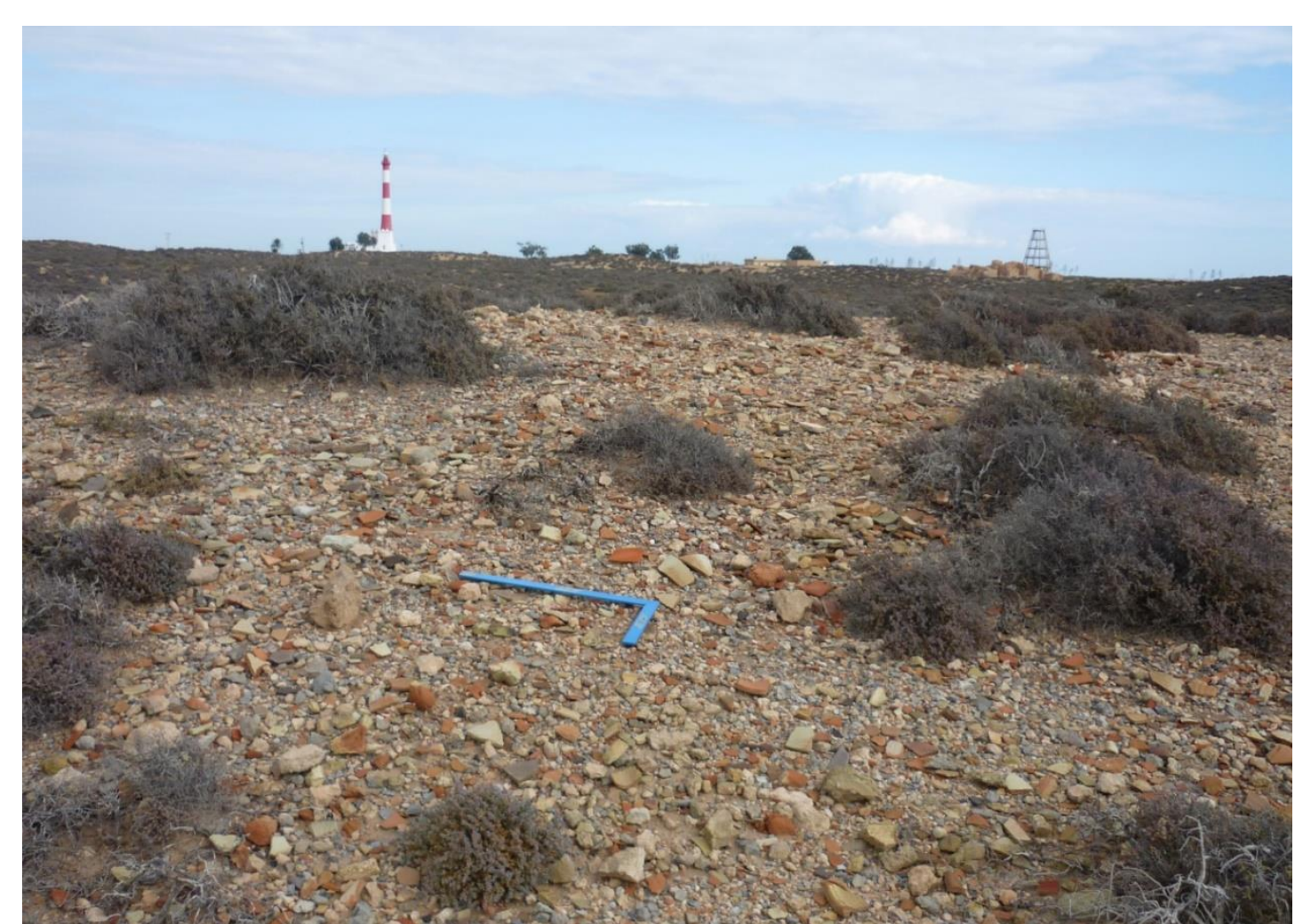

Fig.1: Location of the archaeological site of Thaenae.

Fig. 2. Evidence of amphora workshops at Thaenoe.

\section{Materials and Methods}

The PhD research deals with the various ceramic classes imported or locally produced in Thaenae, many samples of which were collected during field surveys in 2017 and 2018 (Fig.2), and particular importance will be given to the African Red Slip (ARS) ware. This is because ARS relatively fine-grained, homogeneous body fabrics and very fine, Fe-rich clayey coatings are particularly appropriate to an integrated archaeometric approach combining the mineralogical-petrographic (thin-section) analysis and the geochemical methods. As for the latter, we are testing on this subject the recently developed portable XRF (using a Brucker Trace IV SD), that is a non-destructive method. The analysis is carried out on both the body and the slip

As the investigation on Thaenae samples is in progress, we will present here some preliminary results concerning the analysis of reference materials from a few ARS workshops of northern Tunisia and the collection of Gap Museum (France). The latter
is predominantly composed - according to typology and petrography - of products from Sidi Aich workshop (or area), in Tunisian inland, which is the potential source of many imports to Thaenae.

\section{Results}

\section{1- The Gap collection}

In a preliminary study [3] a few ARS samples from the Gap collection were compared with each other and with some known references materials [4]. Although the analyses were carried out on a limited number of specimens, the combined typological, petrographical and geochemical approach lead to rather good results:

-The archaeological study allowed the identification of three main ARS groups, one of wich possibly related to Sidi Aïch [3] (Fig. 3 and Table 1). Some outliers were referred to different unknown productions.

- The petrographic analysis identified two rather homogeneous groups (Fig. 3 and Table 1) and some outliers, in most cases in good correlation with the archaeological hypotheses, especially concerning Sidi Aïch [3].

The geochemical data evidenced some groups and outliers, only partly in agreement with the archaeological and petrografical results (Table 1) [3].
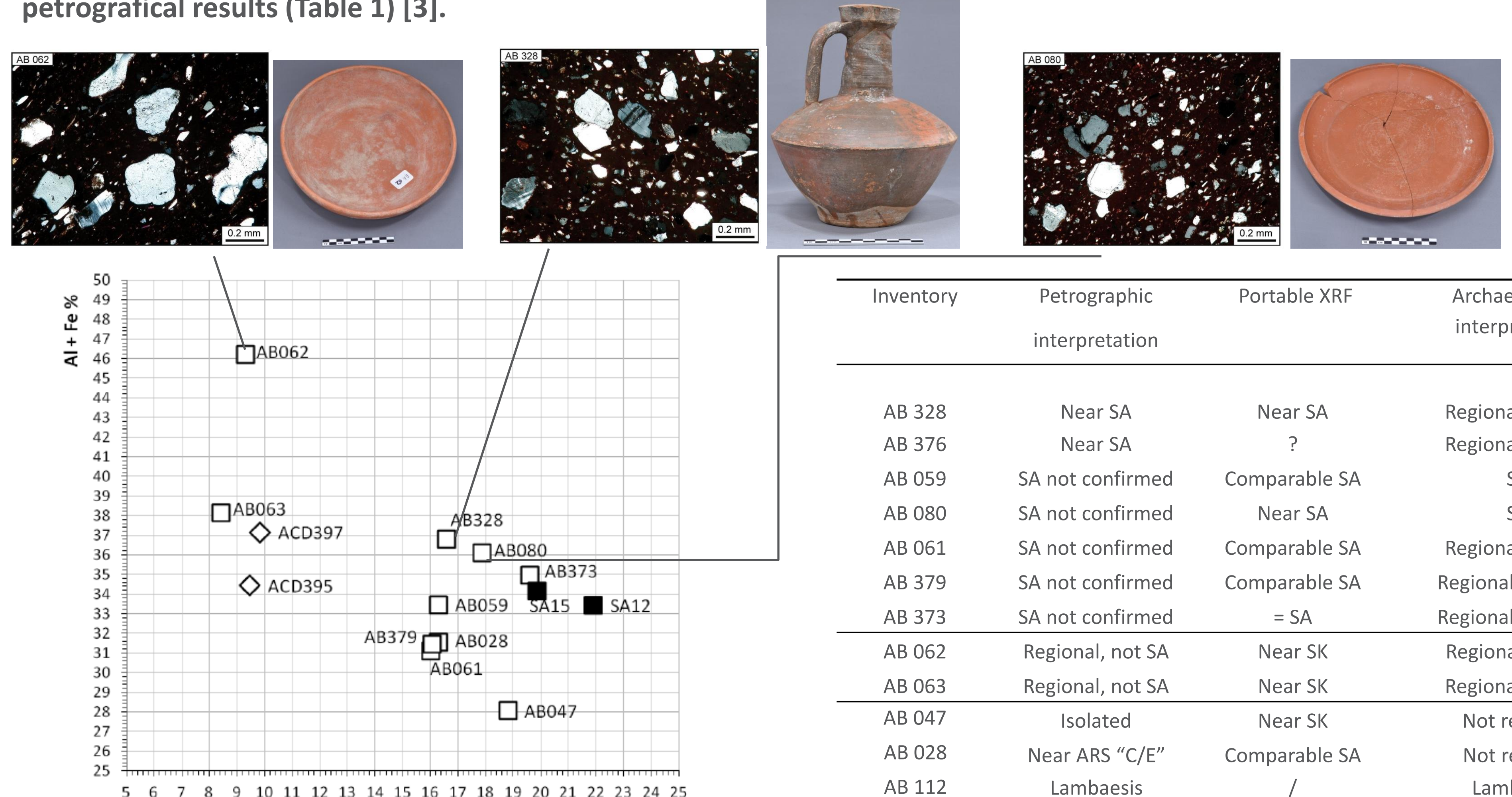

Fig. 3: XRF chemical composition in the binary diagram Al+Fe vs, Khalifa (ACD) and Sidi Aïch (SA) workshops (from [4]).

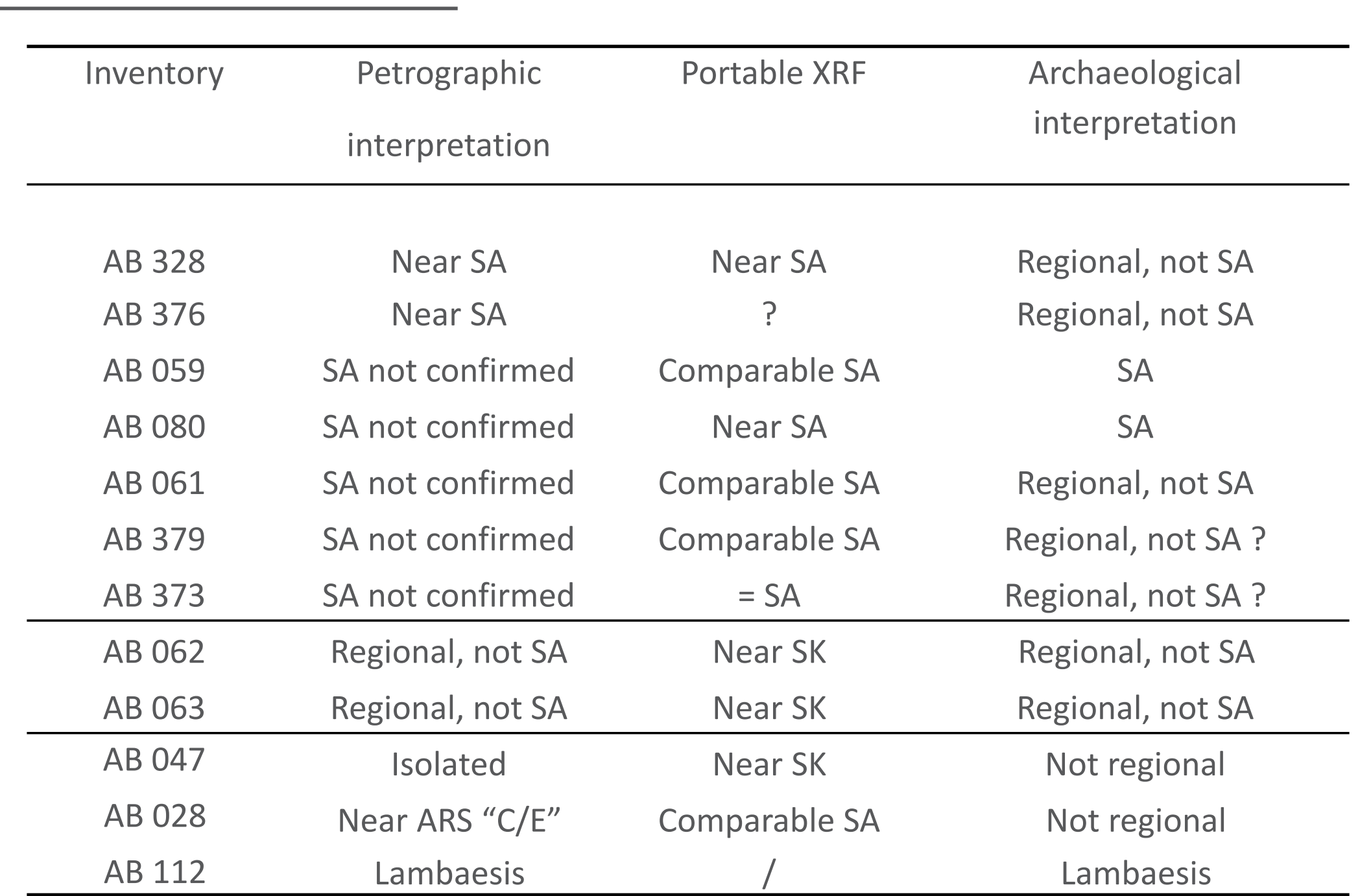

Table 1. Summary of archaeological, petrographical and geochemical results (from [4])

\section{Results}

2- New XRF analysis on ARS workshop samples

Further analyses with portable XRF are needed to test the new method and determine the distinguishing features of each African production. In this way, we are building a portable XRF database related to the main ARS workshops, that are already studied archaeologically, petrographically and by classical WD-XRF [4][5].

We present here the results of the analysis of representative samples from $\mathbf{3}$ well-known ARS workshops (Oudhna, El Marhine and Sidi Khalifa) close to the northern Tunisian coast and 2 inland workshops (Sidi Aich and Djilma). Both the ceramic body and the slip were investigated. The results are also compared with those on the Gap collection.

Firstly the new results, even if still preliminary, showed that the inland workshops and those from the northern Tunisian coast form two separate groups taking into account a few elements, such as K (Fig. 4). Body and slip analyses lead to similar results. Moreover, especially if the slip data and other chemical elements are considered, such as Al (Fig. 5), also the single investigated workshops could be distinguished one from another.

Secondly, the Gap collection samples form two different groups, a major and a minor one, which are broadly comparable with those composed by the inland and costal workshops references. However, the larger compositional variability of the major group seems to point to multiple inland sources, only partly consistent with the workshop groups and Sidi Aïch in particular (Fig. 4 and 5).

The minor group, composed of two samples, could be attributed to imports from unknown workshops, possibly from the coastal area.

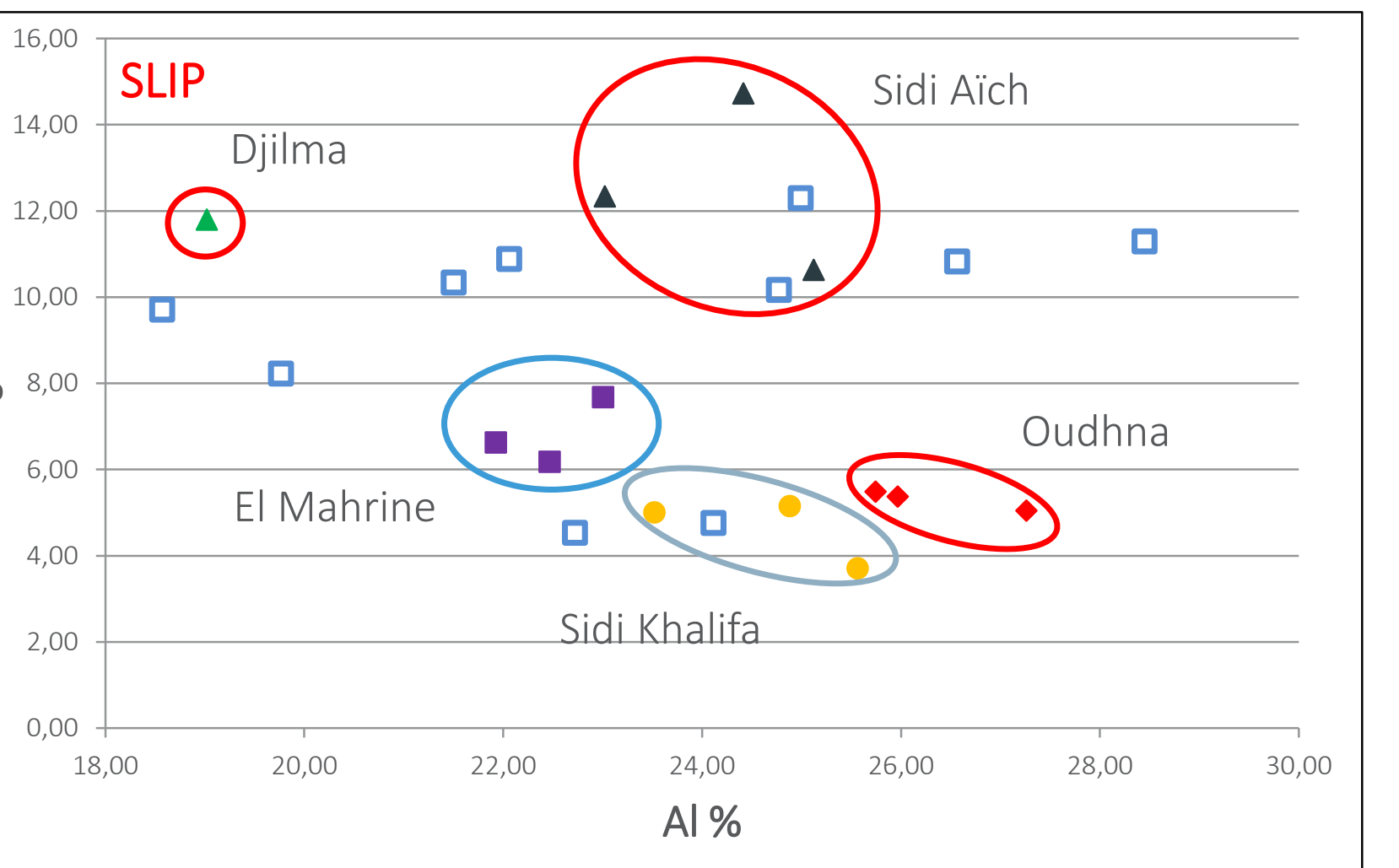

Fig.4: Binary diagram K - Al of the slip surface

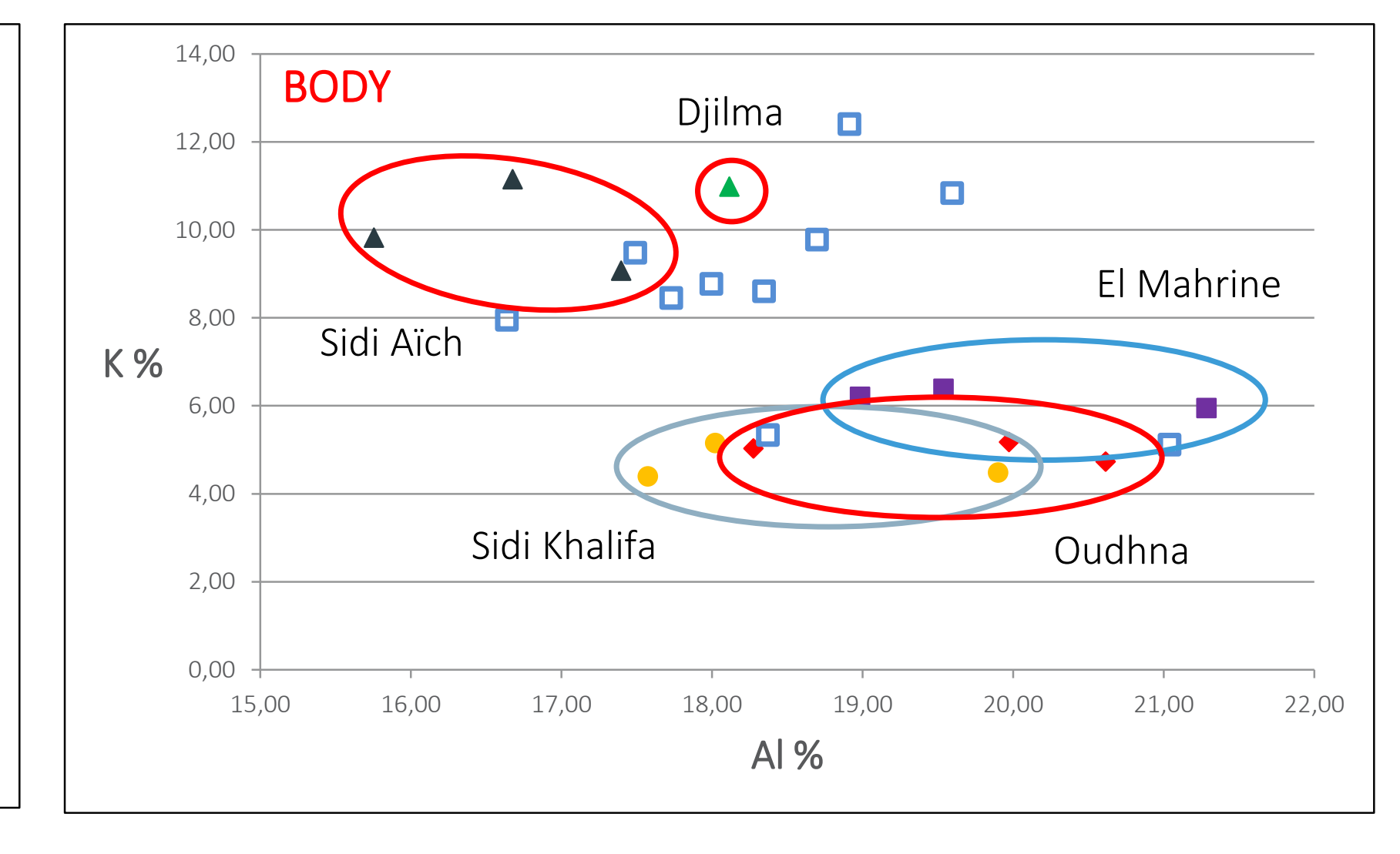

Chemical composition (by portable XRF) of ARS samples

from Tunisian workshops and the Gap collection (empty squares)

\section{Discussion and Conclusions}

- These first results are promising, especially if the slip data are considered. However, more analyses in terms of samples and workshops are needed to confirm these results, resolve measure variability and put in evidence the distinguishing elements of each production especially as for the inland workshops.

- Even if it is still preliminary, this study showed the potentiality of the non-destructive portable XRF analysis on African Red Slip Ware. These results point to the possibility of distinguishing the main ARS productions from each other by portable XRF. The integrated approach in combination with typology and petrography will allow a control of the results and the correct development of the method. This combined approach will be extended to the study of African amphorae and common wares.

- The improvement of the analytical database of reference materials from the workshops and the parallel study of Thaenae samples could give the possibility of distinguishing the local production from the imports and identify the sources of the latter

- Moreover, this method will be applied to other Mediterranean consumption sites in order to contribute to identify the origin of the African pottery. The non-destructive XRF will also allow to characterize entire objects from the museums, that are impossible to analyse with the classical petrographic or chemical methods.

- In a general way, this interdisciplinary research project will also provide important data about the exchange routes between the internal regions and the Tunisian coast and also between Roman Africa and the rest of the Mediterranean.

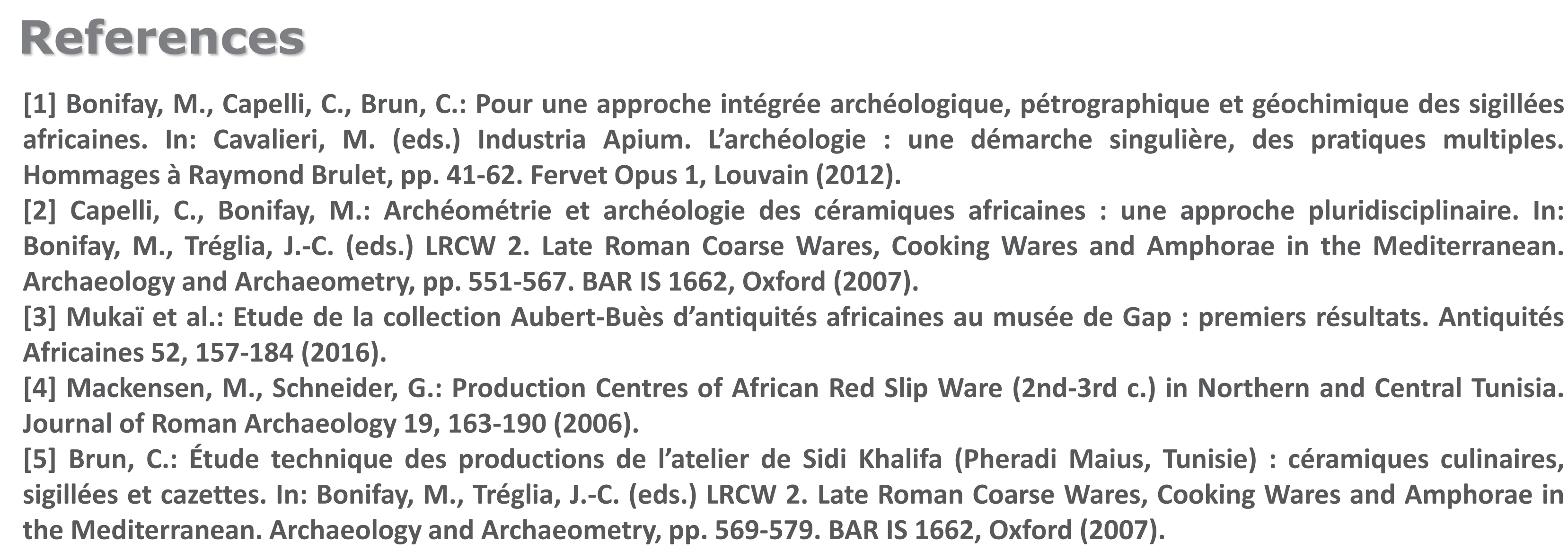

Acknowledgement

Carried out with the permission of the Institut National du Patrimoine, this work was financially supported by Aix Marseille
Universite, the University of Sfax and the "PHC Utique" program of the French Ministry of Foreign Affairs and Ministry of

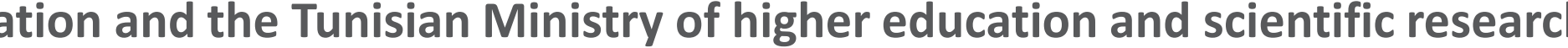

